\title{
Therapeutic Potential Assessment of Green Synthesized Zinc Oxide Nanoparticles Derived from Fennel Seeds Extract
}

This article was published in the following Dove Press journal: International Journal of Nanomedicine

\author{
Mohamad S AISalhi ${ }^{1,2}$ \\ Sandhanasamy Devanesan (iD) ${ }^{1,2}$ \\ Muhammad Atif ${ }^{1,2}$ \\ Wedad S AIQahtani ${ }^{3}$ \\ Marcello Nicoletti ${ }^{4}$ \\ Paola Del Serrone 5 \\ 'Research Chair in Laser Diagnosis of \\ Cancers, Department of Physics and \\ Astronomy, College of Science, King Saud \\ University, Riyadh II45I, Kingdom of \\ Saudi Arabia; ${ }^{2}$ Physics and Astronomy \\ Department, College of Science, King \\ Saud University, Riyadh, Kingdom of \\ Saudi Arabia; ${ }^{3}$ Department of Forensic \\ Sciences, College of Criminal Justice, Naif \\ Arab University for Security Sciences, \\ Riyadh, II45I, Saudi Arabia; \\ ${ }^{4}$ Department of Environmental Biology, \\ Sapienza University of Rome, Rome \\ 00185, Italy; ${ }^{5}$ Council for Agricultural \\ Research and Economics, Research \\ Center for Zootechnic and Aquaculture, \\ Monterotondo, Rome, 000I5, Italy
}

Correspondence: Sandhanasamy Devanesan; Muhammad Atif Research Chair in Laser Diagnosis of Cancers, Department of Physics and Astronomy, College of Science, King Saud University, Riyadh II45I, Kingdom of Saudi Arabia

Email sdnesan1981@gmail.com
Purpose: To study the cytotoxic evaluation, antimicrobial and confocal analysis of zinc oxide nanoparticles ( $\mathrm{ZnO}$ NPs) obtained from a novel plant product fennel (Foeniculum vulgare Mill.) seed extract (FSE).

Methods: ZnO NPs were analyzed using UV-Vis spectroscopy, XRD, FTIR, TEM and EDX techniques. The MTT cell cytotoxicity assay measured the proliferation and survival of MCF-7 cells treated at different concentrations of FSE-derived ZnO NPs. The antimicrobial activity towards pathogenic bacteria and yeast strains was investigated.

Results: The UV-Vis spectra showed two peaks at $438 \mathrm{~nm}$ and $446 \mathrm{~nm}$, confirming nanoparticle formation. The SEM morphology results showed porous ranging from 23-51 $\mathrm{nm}$. The antitumor activity value $\left(\mathrm{IC}_{50}\right)$ was at $50 \mu \mathrm{g} / \mathrm{mL}$ and $100 \mu \mathrm{g} / \mathrm{mL}$. Besides, morphological changes of MCF-7, cells treated at different concentrations of FSE of ZnO NPs were observed in cell cultures transfected with a transient pCMV6-XL4-GFP-expressing vector containing C-terminal domain GFP-tagged proteins, which resulted in an apoptotic effect. Antimicrobial IZ ranged up No Inhibition to $18.00 \pm 0.4$. The IZ revealed at the highest concentration was E. faecium VRE and yeast Cryptococcus sp. (18.00 $\pm 0.4 . \mathrm{mm})$, followed by $S$. aureus $(17.00 \pm 0.2 \mathrm{~mm})$ and $P$. aeruginosa and the yeast $C$. parapsilosis $(16 \pm$ $0.4 \mathrm{~mm}$ ). The IZ was equal to that caused by the nystatin to Cryptococcus sp., which was significantly highest than ampicillin treatments of $S$. aureus, P. aeruginosa, C. albicans, and C. parapsilosis. The MIC value of the FSE-derived $\mathrm{ZnO}$ NPs tested against E.faecium and C. albicans was $6.00 \mu \mathrm{g} / \mathrm{mL}$ (E. faecium and C. albicans). It was $32.00 \mu \mathrm{g} / \mathrm{mL}$ (S. aureus, $S$. typhimurium and Cryptococcus sp.), $64.00 \mu \mathrm{g} / \mathrm{mL}$ (P. aeruginosa), and $128 \mu \mathrm{g} / \mathrm{mL}(C$. parapsilosis).

Conclusion: As far as it is to our knowledge, this study established, for the first time, the biological activities of biosynthesized ZnO NPs from FSE and their synergistic therapeutic potential.

Keywords: fennel seed extract-derived zinc oxide nanoparticles, green nanotechnology, anti-tumor activity, antimicrobial activity and therapeutic agents

\section{Introduction}

In the last decade, efficient green chemistry methods for synthesizing metal nanoparticles (MNPs) were developed to find an eco-friendly technique for producing well-characterized nanoparticles using organisms. Among them, plants are suitable for large-scale biosynthesis of nanoparticles. Plant-derived nanoparticles resulted in more stable and faster synthesized than in the case of microorganisms. Also, plants produce more various nanoparticles, either in shape or in size. ${ }^{1-6}$ 
The nanoparticles have broad-spectrum applications in health care, cosmetics, biomedical food and feed, drug/ gene delivery, environmental studies, mechanics, optics, light limiters, nonlinear optical and photoelectron chemical applications, and that rely on the different synthesis processes. In UV-visibleregions, the versatile semiconductor behavior, their momentous optical transparency and luminescent properties and their applications in solar cells, ceramics, and catalysts, cosmetics, gas sensors, and lighting arrestors. ${ }^{8,9}$ Additionally, these nanoparticles have turned out to be essential for their excellent chemical and thermal stability. ${ }^{10}$

$\mathrm{ZnO}$ NPs have remarkable fluorescence in cells so that they are biomarkers in relevant clinical and biomedical applications. ${ }^{11}$ They have emerged as a promising and innovative technique for the efficient delivery of drugs in treating some diseases by specific targeting. ZnO NPs are also used in rubber and daily care products like sunscreen and cosmetics. ${ }^{12}$ Moreover, ZnO NPs have excellent UVblocking, anticancer, and antimicrobial properties. ${ }^{13-17} \mathrm{~A}$ recent review reported the importance of $\mathrm{ZnO}$ NPs in medical applications, mainly ZnO NPs as the right choice for wound healing, antibacterial antioxidant activities. The ZnO NPs are on par with the therapeutic applications of cellulose, chitosan, and alginate polymer alone. ${ }^{18}$

$\mathrm{ZnO}$ NPs have been prepared and developed using numerous approaches and techniques, eg, hydrothermal methods, spray pyrolysis, sol-gel, chemical vapor deposition, ultrasonic conditions, precipitation methods, and microwave-assisted techniques. ${ }^{19}$ The precipitation method's basis depends on drying and controlled processes of the obtained material that are thermally treated at different temperatures. ${ }^{20}$

The waste from the essential oil distillation from aromatic plants contains antioxidant compounds, such as polyphenols and flavonoids (kaempferol and quercetin), that is an added value. ${ }^{21}$ The fennel seed extract includes $2 \%$ to $6 \%$ volatile oil, which is obtained by steam distillation. It is used in cosmetics, pharmaceuticals, and the plant is utilized as a spice (seeds) and a vegetable (tuber). ${ }^{10}$ In the last years, the water extraction process of the fennel seeds was optimized to produce extracts containing more valuable bioactive substances. The yield of polyphenols, flavonoids, and the total dry extract are higher when using water as a solvent. The water extracts of fennel seeds have a higher antioxidant capacity, which might be attributed to the higher content of the raw material, polyphenols. The yield of total extract and bioactive components improved at higher temperature. The extracted mass was $16-18 \%$ of the total mass. ${ }^{22-24}$

The present study aims to combine a comfortable, safe, and cheap method as the water extraction of fennel seed with the use of the FSE to produce ZnO NPs. As far as it is to our knowledge, this study established the biological activities of biosynthesized $\mathrm{ZnO}$ NPs from fennel extract and their therapeutic potential for the first time.

\section{Materials and Methods}

\section{Fennel Seed Extraction}

Commercial $(500 \mathrm{~g})$ fennel seeds were washed several times with tap water and $\mathrm{dd} \mathrm{H}_{2} \mathrm{O}$, then dried at room temperature. After washing treatment, the cleaned seeds were blended as a fine powder for extract preparation. The fennel seed powder $(10 \mathrm{mg})$ was soaked with $50 \mathrm{~mL}$ of dd $\mathrm{H}_{2} \mathrm{O}$ for 24 hours and then filtered with Whatman No. 1 filter paper according to water extraction to produce more concentrated antioxidants (polyphenols and flavonoids). ${ }^{5,24}$

\section{Synthesis and Characterization of $\mathrm{ZnO}$ NPs}

$\mathrm{ZnO}(41.3 \mathrm{mg})$ was poured into $250 \mathrm{~mL}$ dd $\mathrm{H}_{2} \mathrm{O}$. FSE 10 $\mathrm{mL}$ was added, and the solution was thoroughly mixed for $5 \mathrm{~min}$ in a shaking incubator. The reaction mixture was maintained at $99^{\circ} \mathrm{C}$ for $1 \mathrm{~h}$, when the color change from light yellow to dark yellow occurs, indicating the reduction in the number of zinc ions and the synthesis of $\mathrm{ZnO}$ NPs. After $5 \mathrm{~min}$, the decanted solution was centrifuged at 15,000 RPM for $10 \mathrm{~min}$, and the process was repeated four times to remove unwanted particles. Finally, purified $\mathrm{ZnO}$ NPs were collected, and further analysis was performed.

$\mathrm{ZnO}$ NPs optical properties were measured by UV absorption spectra in the wavelength range of 200-800 nm. XRD analysis was executed on an X-ray diffractometer (PAN analytical X-Pert PRO, UK) to determine the nanoparticles' crystal density, purity, and size. FTIR spectral measurements were performed to identify the potential biomolecules in fennel seeds (benchtop Cary 670 FTIR Spectrometer, Agilent Technologies, USA). TEM was used to analyze the shapes and sizes of the particles. SEM was used to calculate the size of the nanoparticles. EDX was applied to analyze the elemental compositions of the ZnO NPs (SEM-EDX Oxford Instruments Analysis, UK). 


\section{Cell Culture and Transfection}

MCF-7 cell lines (ATCC ${ }^{\circledR}$ HTB-22 ${ }^{\text {TM }}$ Manassas, VA, USA) were transfected with pCMV6-XL4-GFP-expressing vector containing the $\mathrm{C}$-terminal domain GFP-tagged proteins with human full-length cDNA clones of nuclear proteins (pCMV6-XL4-USP20, OriGene USA). The MCF-7 cells (Grand Island, NY, USA) were grown in DMEM supplemented with 10\% FBS, (100 U) $20 \mu \mathrm{g} / \mathrm{mL}$ penicillin, and $100 \mu \mathrm{g} / \mathrm{mL}$ streptomycin. Incubation was carried out at $37^{\circ} \mathrm{C}$ with an atmosphere of $5 \% \mathrm{CO}_{2}$. Normal breast (MCF-7) cells were cultured in a 1:1 mixture of DMEM and Ham's F12 medium with $20 \mathrm{mg} / \mathrm{mL}$ of EGF, $100 \mu \mathrm{g} / \mathrm{mL}$ cholera toxins, $0.01 \mathrm{mg} / \mathrm{mL}$ insulin and $500 \mu \mathrm{g} / \mathrm{mL}$ hydrocortisone, and $5 \%$ chelex treated horse serum. Purified berberine and tamoxifen were dissolved in DMSO and used for the bioassay.

The MCF-7 cells were cultured DMEM, with 10\% fetal bovine serum, $0.2 \%$ sodium bicarbonate, and antibiotic/antimycotic solution $(100 \mu \mathrm{g} / \mathrm{mL}$ streptomycin and 100 $\mathrm{U} / \mathrm{mL}$ penicillin). The cells were grown in $5 \% \mathrm{CO}_{2}$ at $37^{\circ}$ $\mathrm{C}$ in a high-humidity atmosphere. After homogenization, 1 $\mathrm{mL}$ of the suspension was transferred to each well of the microtiter plate. And, reagents utilized in this study were purchased from Sigma-Aldrich (Gillingham, UK).

\section{Cytotoxicity Assays}

FSE-derived $\mathrm{ZnO}$ NPs $(0.05 \mathrm{~mL})$ were dissolved in 4.95 $\mathrm{mL}$ of DMSO to get a working concentration of $1 \mathrm{mg} / \mathrm{mL}$. The active concentration was prepared freshly and filtered through $0.45 \mu$ filter before each assay. In brief, $5 \mathrm{~mL}$ of extract was prepared in a concentration of $1 \mathrm{mg} / \mathrm{mL}$. For each sample, $500 \mu \mathrm{L}$ were poured in eight Eppendorf tubes. The samples were syringe-filtered using $0.45 \mu \mathrm{M}$ filter to remove contaminants. $500 \mu \mathrm{L}$ of the sample's working concentration was further added to the first Eppendorf tube and mixed well. Then, $500 \mu \mathrm{L}$ of this volume was transferred from first to last tube by serial dilution to obtain the desired concentration of the $\mathrm{ZnO}$ NPs. As a result, the volume remains constant, but there was a gradual change in concentration. The cytotoxicity assessment was performed using MTT, NRU assay, and morphological changes following the methods described in previous reports. ${ }^{25-27}$

For this assay, MCF-7 cells were plated in 96-well culture plates $\left(1 \times 10^{4}\right.$ cells/well). The cells were exposed to concentrations of 5, 10, 25, 50, and $100 \mu \mathrm{g} / \mathrm{mL}$ of $\mathrm{ZnO}$ NPs for 24 hours. The measurements were performed in triplicate. The colors developed in the plates were read at $550 \mathrm{~nm}$ by using DMSO as a blank. The percentage of cell viability was expressed using the following formula:

$\%$ cell viability $=$ mean absorbance of treated cells/ mean absorbance of control cells $\times 100$

\section{Cell Treatment and Characterization}

When the cells reached $90 \%$ confluence, the MCF-7 cells were cultured in 96-well plates with an initial cell density of $2 \times 10^{4}$ per well. The cells were then treated with FSEderived $\mathrm{ZnO} \mathrm{NPs}$ at five different concentrations (five experimental groups as described above). All the experimental groups were incubated at $37^{\circ} \mathrm{C}$ in a $5 \% \mathrm{CO}_{2}$ incubator 24 hours. The culture medium was removed and washed three times with $1 \mathrm{X}$ PBS, and one group of the cells was left untreated, a control group.

The cells were fixed with $4 \%$ paraformaldehyde for 10 min at room temperature, followed by washing with cold PBS twice. The cells were stained with $1 \mu \mathrm{L} / \mathrm{mL}$ DAPI for $5 \mathrm{~min}$. Then, the stained cells were rinsed with PBS, followed by staining the cells with $1 \mu \mathrm{L} / \mathrm{mL}$ of red-fluorescent Alexa 594 phalloidin to examine the actin networks' integrity at a high resolution. The cells were examined under inverted phase-contrast microscopy at 40X magnification (Carl Zeiss Microscopy GmbH, DE). All cited chemical products are from Sigma (USA).

\section{Collection of Microorganisms}

The bacteria Staphylococcus aureus ATCC 43300, Bacillus subtilis WS15, ESBL-producing Escherichia coli ATCC 9637, Salmonella typhimurium ATCC 14028, Enterococcus faecium VRE, Pseudomonas aeruginosa ATCC 27584, and Klebsiella pneumoniae ATCC 13883, and the yeast Candida albicans ATCC 8436, C. parapsilosis ATCC 22019 and Cryptococcus sp. were kindly provided by the King Khalid Medical City, King Saud University collection.

\section{Antimicrobial Assay}

Ten pathogenic strains of bacteria and yeast were selected for their sensitivity to FSE-derived $\mathrm{ZnO}$ NPs vs commercial antibiotics, viz. ampicillin $(10 \mu \mathrm{g})$, and nystatin (50 $\mu \mathrm{g}$ ), respectively, by well diffusion method. ${ }^{27,28}$ Following the CLSI methodology, FSE and derived ZnO NPs and antibiotics were aseptically placed on MHA plates. They were then inoculated with $1 \times 10^{8} \mathrm{CFU} / \mathrm{mL}$ of bacterial and yeast cultures. The bacteria and yeast inoculated plates were incubated for 24 hours at $37^{\circ} \mathrm{C}$ and $30^{\circ} \mathrm{C}$. After the 
incubation periods, the inhibition zones $(\mathrm{mm})$ were observed, and their measures were recorded. Three repetitions for each thesis were considered, and the experiment was repeated twice.

The MICs of the FSE-derived ZnO NPs were evaluated with the broth microdilution method. ${ }^{29}$ The 0.5 McFarland bacterial and yeast culture suspensions were transferred into each microtiter well plate. Then, various concentrations (ie, 256.00, 128.00, 64.00, 32.00, 16.00, 8.00, 4.00, $2.00,1.00,0.50,0.25$ and $0 \mu \mathrm{g} / \mathrm{mL})$ of the FSE-derived $\mathrm{ZnO}$ NPs were transferred in each well and incubated at $37^{\circ} \mathrm{C}$ and $30^{\circ} \mathrm{C}$, respectively, for 24 hours. Three repetitions were considered, and the experiment was repeated twice.

\section{Statistical Analysis}

The obtained data were processed using IBM $^{\circledR}$ SPSS $^{\circledR}$ Statistics 25.0 version, a statistical software platform. Also, one-way ANOVA was used, and equal variances were assumed for the LSD tests. The values are expressed as means \pm SDs, with p-values less than 0.05 and 0.01 considered statistically significant. ${ }^{28,30}$

\section{Results and Discussion Production and Characterization of $\mathrm{ZnO}$ NPs}

The primary test for ZnO NPs biosynthesis in FSE is a visual color change, as shown in Figure 1A. The optical absorbance of the $\mathrm{ZnO}$ NPs ranged 200-800 nm, as shown in Figure 1B, with a value of the absorption

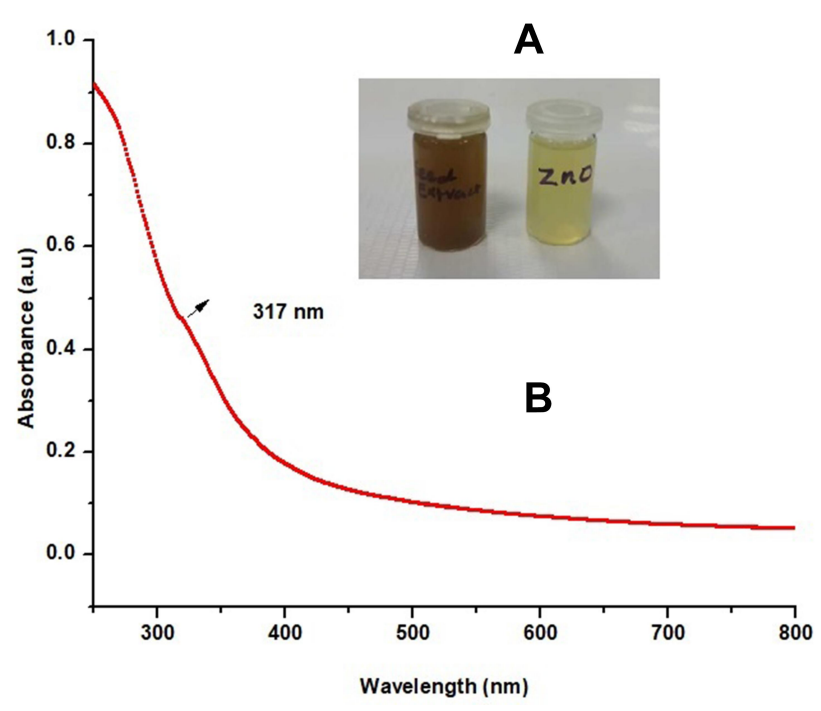

edge at $317 \mathrm{~nm}$. The PL spectra show two peaks at $438 \mathrm{~nm}$ and $446 \mathrm{~nm}$ at room temperature, as shown in Figure $1 \mathrm{C}$, for 48 hours. The relative intensity increased due to more aggregation of $\mathrm{ZnO}$ NPs interacting with the plant source.

The XRD spectra of biosynthesized ZnO NPs indicating the nanoparticles' crystallinity are reported in Figure 2. The X-ray diffraction peaks corresponded to lattice planes of $2.82,2.60,2.48,1.91,1.62$, and 1.48. 1.38. By applying Scherrer equation on the XRD pattern, the particle size can be calculated. ${ }^{5,11,27}$ The crystallite size of the FSE-derived $\mathrm{ZnO}$ NPs calculated from XRD line broadening using the Scherer equation is $36.78 \mathrm{~nm}$.

The FTIR spectrum of ZnO NPs was detected on the peaks at 3405, 2926, 1655, 1499, 1420, 1029, and $547 \mathrm{~cm}^{-1}$ (Figure 3). The vibrational stretching peaks at 3405 and $1420 \mathrm{~cm}^{-1}$ represent hydroxyl groups present in $\mathrm{ZnO}$ NPs. The infrared absorption peaks were observed at 2926 and $1029 \mathrm{~cm}^{-1}$ for $\mathrm{C}-\mathrm{H}$, another at $1655 \mathrm{~cm}^{-1}$ for $\mathrm{C}=\mathrm{O}, 1499 \mathrm{~cm}^{-1}$ for the alkaline group. The peak at $547 \mathrm{~cm}^{-1}$ corresponds to the presence of $\mathrm{ZnO}$ NPs. The presence of a peak at $547 \mathrm{~cm}^{-1}$ supports the formation of $\mathrm{ZnO}$ NPs in FSE.

A TEM image (Figure 4A and B) of the $\mathrm{ZnO}$ NPs at magnifications of 100 and $200 \mathrm{~nm}$ shows that they have a spherical shape. The maximum size was $50.422 \mathrm{~nm}$, and the minimum size was $22.794 \mathrm{~nm}$, and an average of 36.78 nm was achieved.

The EDAX spectrum of the $\mathrm{ZnO}$ NPs is reported in Figure 5. The spectrum shows the chemical constituents

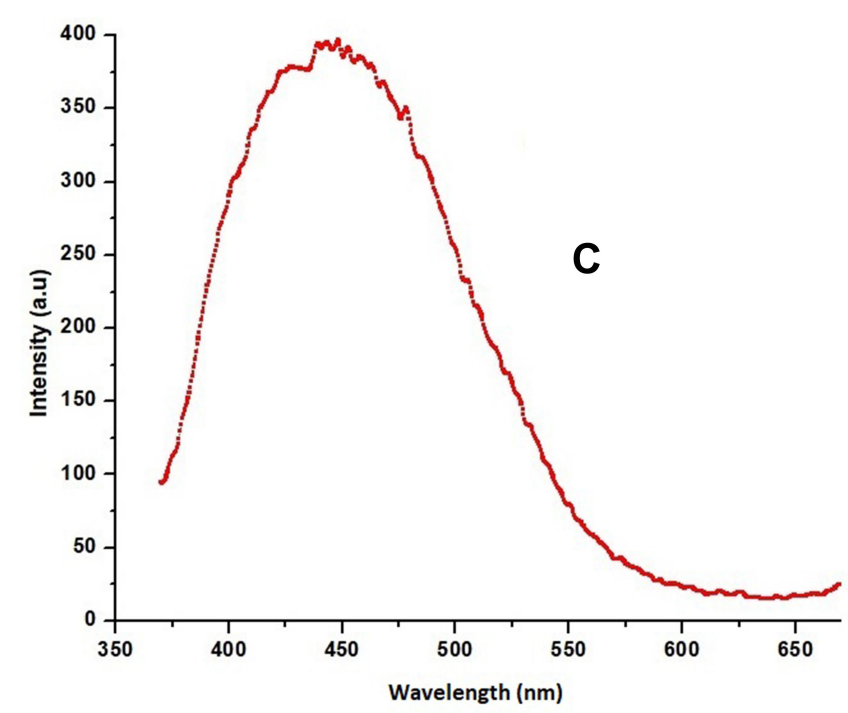

Figure I (A) Color change due to ZnO NPs synthesis in FSE; (B) the absorption spectrum of FSE-derived ZnO NPS; (C) PL Spectra at 48 hours. 


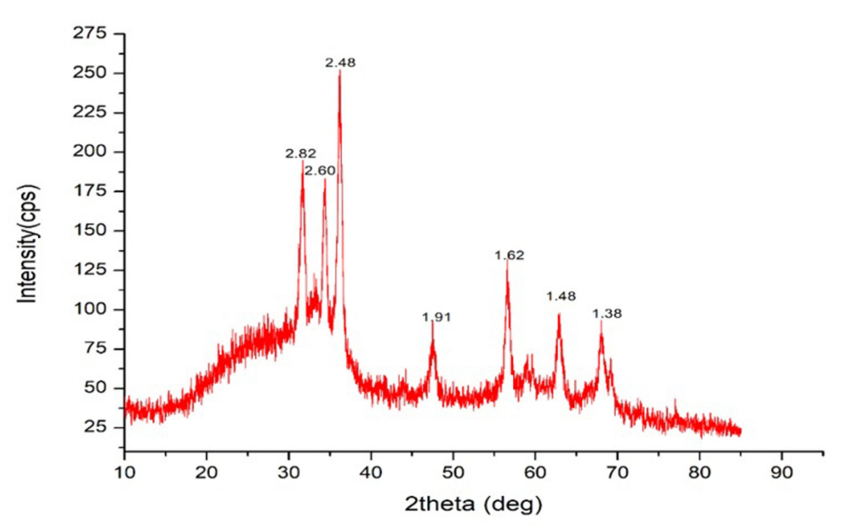

Figure 2 XRD pattern of FSE-derived ZnO NPs.

of Zinc, Oxygen and Carbon present in the samples. This finding confirms that the prepared ZnO NPs samples are in pure form. Green synthesis of ZnO NPs was explained by the bioaccumulated metal ions and their involvement as reductants and stabilizers. ${ }^{31,32}$ The change in color was attributed to zinc nitrate reduction in ZnO NPs. This change resulted in the excitation of surface Plasmon vibrations of the nanoparticles, which led to surface Plasmon resonance, ${ }^{7}$ suggesting the nanoparticle's FCC crystal structure. This reduction was confirmed by different characterization methods, such as XRD, TEM, EDAX, absorption and PL analysis. The spherical shape of the ZnO NPs was less than $100 \mathrm{~nm}$ $(36.78 \mathrm{~nm}) .^{33,34}$

\section{Cytotoxicity Effects of ZnO NPs}

The cytotoxic response of MCF-7 cells exposed to 5, 10, 25, 50 and $100 \mu \mathrm{g} / \mathrm{mL}$ of ZnO NPs assessed by MTT and NRU assays are presented in Figure 6A and B). The MTT and NRU assays showed that FSE-derived ZnO NPs induced a concentration-dependent decrease in the cell viability of the MCF-7 cells in the range of $25-100 \mu \mathrm{g} /$ $\mathrm{mL}$. In the MTT assay, the cell viabilities were $84 \%, 48 \%$ and $24 \%$ at 25, 50 and $100 \mu \mathrm{g} / \mathrm{mL}$, respectively (Figure 6A and Table 1).

In the NRU assay, the cell viabilities were $82 \%, 26 \%$, and $8 \%$ at 25,50 , and $100 \mu \mathrm{g} / \mathrm{mL}$, respectively (Figure 6B and Table 1). The morphological changes in the MCF-7 cells induced by the ZnO NPs are shown in Figure 7, which indicates an apoptotic effect. As shown in Figure 7, the untreated control cells showed normal morphologies in the MCF-7 cells; however, the treatments at 25,50 , and $100 \mu \mathrm{g} / \mathrm{mL}$ showed rounded morphologies and lower cell numbers.

The maximum cytotoxicity results were observed at $100 \mu \mathrm{g} / \mathrm{mL}$. At the highest concentration $(100 \mu \mathrm{g} / \mathrm{mL})$, cell death was observed (Figure 7). Many nanomedicine studies have stated that $\mathrm{ZnO}$ NPs could be used to develop antitumor agents due to their toxic nature. ${ }^{34,35}$ The FSEderived $\mathrm{ZnO}$ NPs cytotoxicity results are in good agreement with those of previous studies. ${ }^{36}$ Reactive oxygen species (ROS) are promoted by phytoconstituents activity. It acts against carcinogens, induced phagocytosis, cell

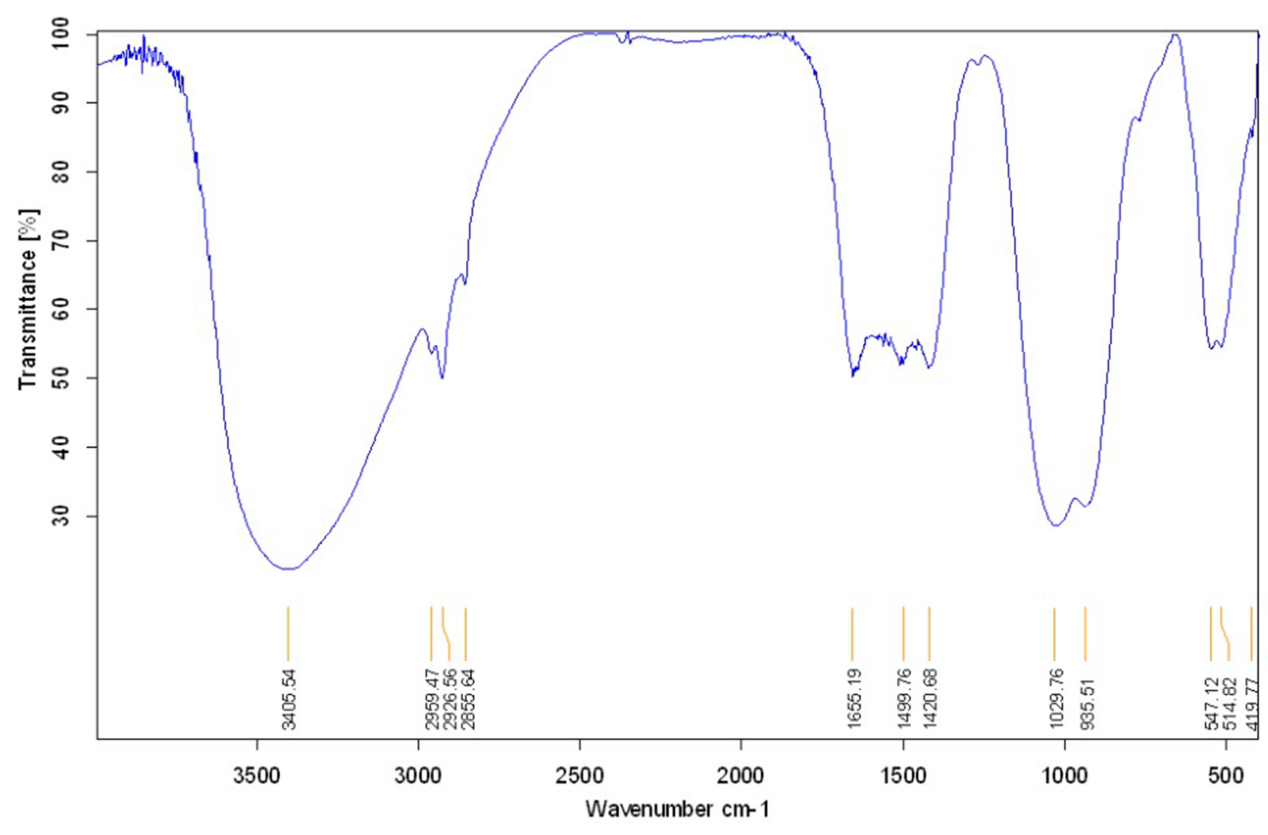

Figure 3 FTIR spectrum of FSE-derived ZnO NPs. 

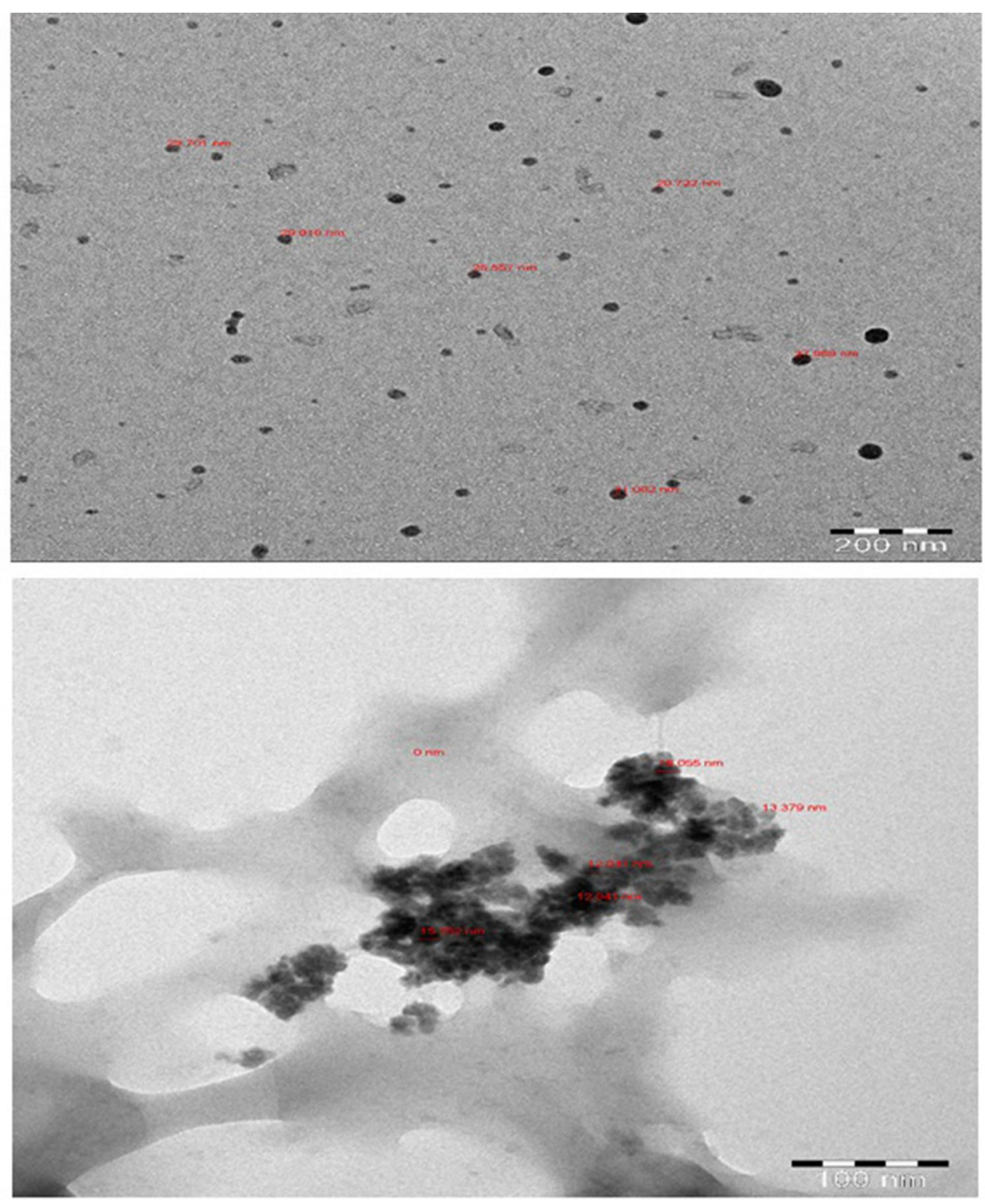

Figure 4 SEM imagines of FSE-derived ZnO NPs at magnification of $100(\mathbf{A})$ and $200 \mathrm{~nm}(\mathbf{B})$.

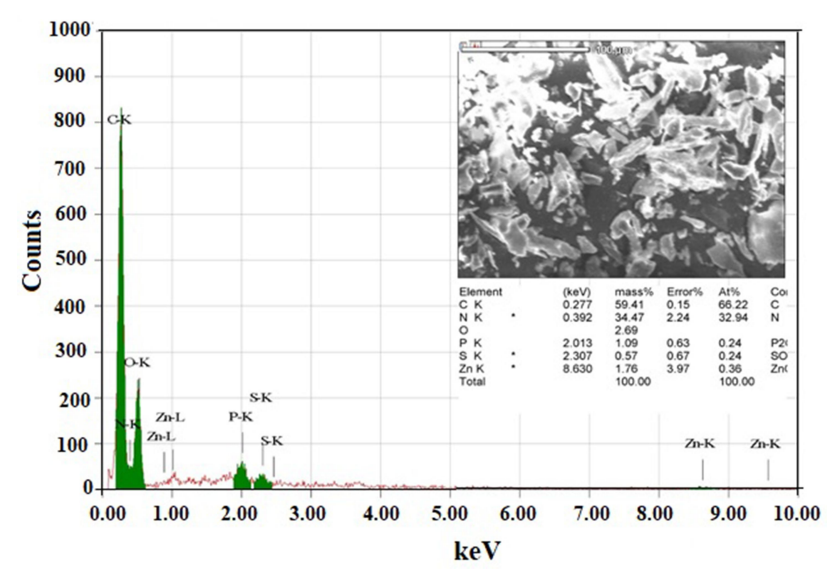

Figure 5 EDAX spectrum of FSE-derived ZnO NPs. proliferation, and intracellular signaling. The basic phenomenon behind the cytotoxicity of ZnO NPs is the intracellular release of dissolved zinc ions in conjunction with ROS induction. This process is due to the induced binary response, including the cell's pro-inflammatory reaction against $\mathrm{ZnO}$ NPs. They can act as a redox system, due to the nanoparticle characteristic surface property. ${ }^{37}$

\section{Confocal Study Performance}

The cytotoxicity study was also performed between the control group and concentrations varying from 1:1, 1:2, $1: 3$ and $1: 4 \mu \mathrm{g} / \mathrm{mL}$. The absorbance estimated viable cells at $570 \mathrm{~nm}$. The anticancer effects of FSE-derived $\mathrm{ZnO}$ 

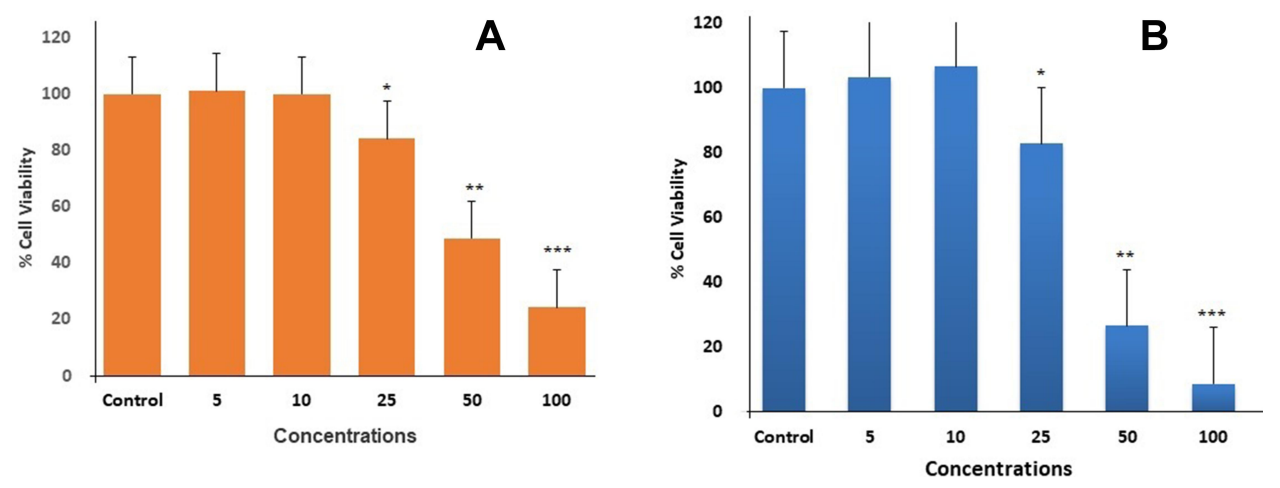

Figure 6 (A) Cytotoxicity assessment by MTT assay in MCF7 cells exposed to various concentrations of FSE-derived ZnO NPs for 24 h. (B) Cell viability assessment by NRU assay in MCF7 cells exposed to various concentrations of FSE-derived ZnO NPs for $24 \mathrm{~h}$. Stars indicate statistically significant differences of cytotoxicity and cell viability assessment between the concentrations of at $\mathrm{p}<0.05$.

NPs on MCF7 cell lines were examined by MTT assay. Concentration-dependent cytotoxicity was observed (Figure 8). The increase in the concentration of $\mathrm{ZnO}$ NPs led to a decrease in the MCF7 breast cancer cell lines' cell viability. Moreover, the sensitivity increased dramatically with the increase in concentration from $1: 1 \mu \mathrm{g} / \mathrm{mL}$ to $1: 4$ $\mu \mathrm{g} / \mathrm{mL}$, as shown by decreased cell proliferation. The $\mathrm{IC}_{50}$ values of the FSE-derived $\mathrm{ZnO}$ NPs against the MCF7 cells were $1: 2,1: 3$ and $1: 4 \mu \mathrm{g} / \mathrm{mL}$.

In this study, the effect of FSE-derived $\mathrm{ZnO}$ NPs on MCF7 cell lines was also evaluated using confocal microscopy of fixed MCF7 cells in culture transfected with transiently pCMV6-XL4-GFP expressing vector containing C-terminal domain GFP-tagged proteins. Untreated control cells had a normal healthy shape with visible round nuclei. DAPI staining shows the altered nuclear shape and neighboring DNA fragments in the nuclei. The current study using fennel seeds extract of ZnO NPs confirmed the previous studies. ${ }^{38,39}$

Table I MTT and NRU Assay with Cell Viabilities of Cytotoxicity Assays

\begin{tabular}{|l|l|l|}
\hline \multicolumn{2}{|l|}{ MCF- 7 Cell Lines Cytotoxicity Assays } \\
\hline Concentrations( $\mu \mathrm{g} / \mathrm{ml})$ & NRU (\%) & MTT (\%) \\
\hline 5 & - & - \\
10 & - & - \\
25 & 82 & 84 \\
50 & 26 & 48 \\
100 & 8 & 24 \\
\hline
\end{tabular}

Notes: Antimicrobial activity by well diffusion test of FSE-derived ZnO NPs at different concentrations $(15,25,50 \mu \mathrm{g} / \mathrm{mL})$ towards the ten selected pathogens grew at $37^{\circ} \mathrm{C}$ (bacteria) and $30^{\circ} \mathrm{C}$ (yeast) for $24 \mathrm{~h}$; The experiment was repeated twice; tree replications for each experiment; upper-case letters to indicate results significant at the 0.05 level and lower-case to indicate results significant at the $0.00 \mathrm{I}$ level.
Figure 9 shows the morphological changes in MCF7 cells at serial concentrations of $1: 1,1: 2,1: 3$, and $1: 4 \mu \mathrm{g} /$ $\mathrm{mL}$ of FSE-derived $\mathrm{ZnO} \mathrm{NPs}$, showing fragmented nuclei (apoptotic cells) in the treated cells confirming MTT and NUR assay. Rodríguez-León et al discussed gold nanoparticles using Mimosa tenuiflora extract cells analyzed by confocal microscopy in two sizes: the smallest AuMt1 and largest AuMt2. The results indicate that the NPs have not entered into the nucleus leading to little or no genotoxic potential. Cellular uptake efficiency is dependent on shape, charge, coating, and NP size, which can change their interactions with cell proteins. Polyphenolic compounds on the AuMt surface confirm nanomaterial internalization, which demonstrates the pharmacological nanocarrier activity. AuMt1 material is spread into the cytoplasm and focused on the nuclear periphery. ${ }^{37}$ The toxicity of the synthesized nanoparticles was evaluated with $\mathrm{MCF}-7$ cells at different concentrations $(5-100 \mu \mathrm{g} / \mathrm{mL})$. The cell toxicity reached a maximum at $100 \mu \mathrm{g} / \mathrm{mL}$. Morphological alterations were found at $100 \mu \mathrm{g} / \mathrm{mL}$ due to cell debris. The confocal microscopy results of the MCF7 cells at different concentrations $(1: 1,1: 2,1: 3$ and $1: 4 \mu \mathrm{g} / \mathrm{mL})$ displayed apoptotic cells in the treated cells. Besides, confocal images of MCF7 cells showed less number of the cells at the concentrations of $1: 3$ and $1: 4 \mu \mathrm{g} / \mathrm{mL}$ of $\mathrm{ZnO}$ NPs due to the weak interconnection of the cellular structure and excess fragments that promoted the killing of the target region against cancer cells. ${ }^{40}$

\section{Antimicrobial Effects of Selected Pathogens}

The experimental outcomes validated that the antimicrobial activity (Figure 10) existed with the FSE- 


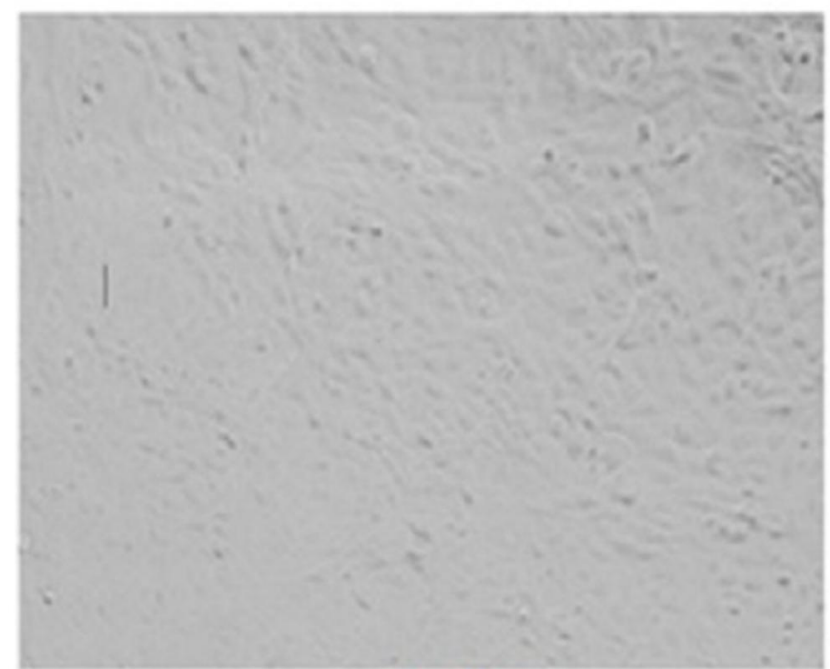

Control

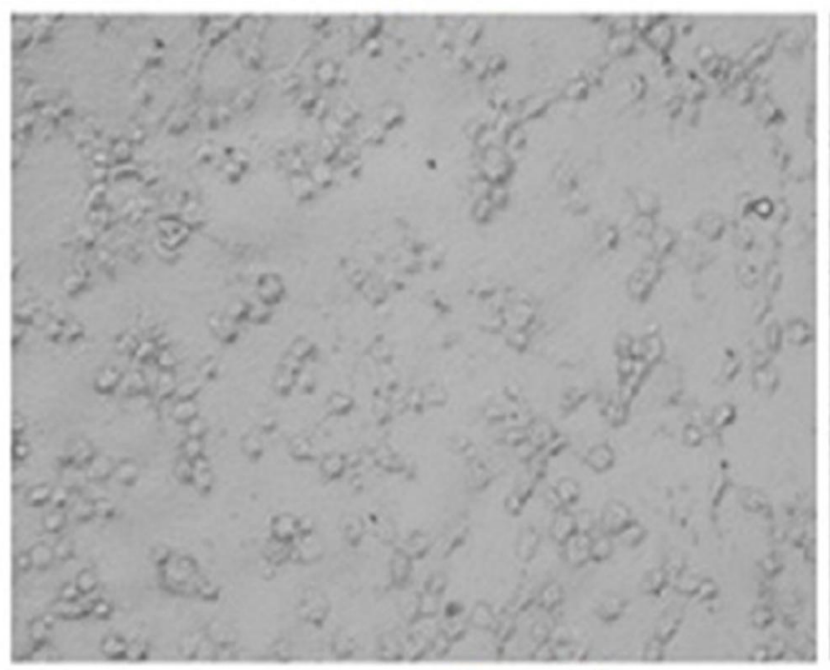

$50 \mu \mathrm{g} / \mathrm{ml}$

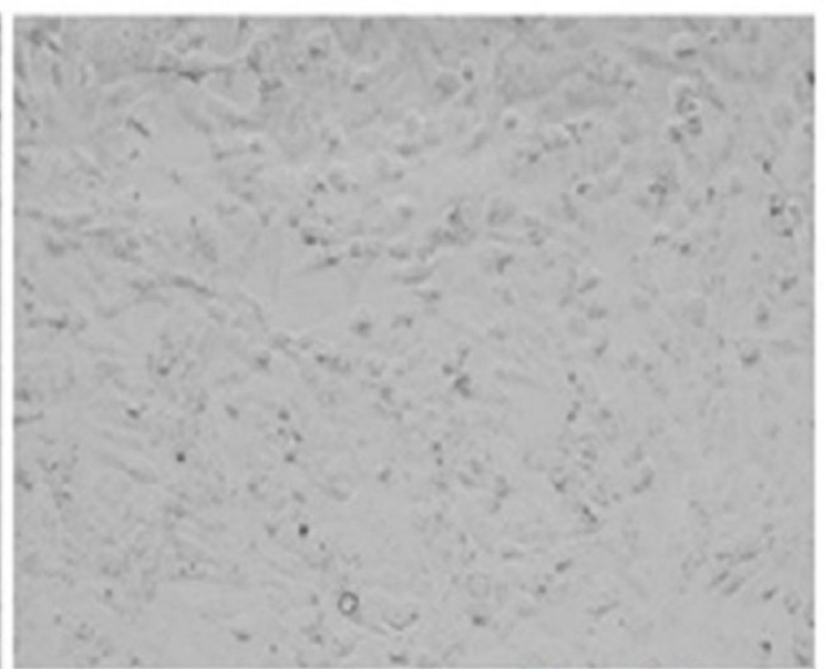

$25 \mu \mathrm{g} / \mathrm{ml}$

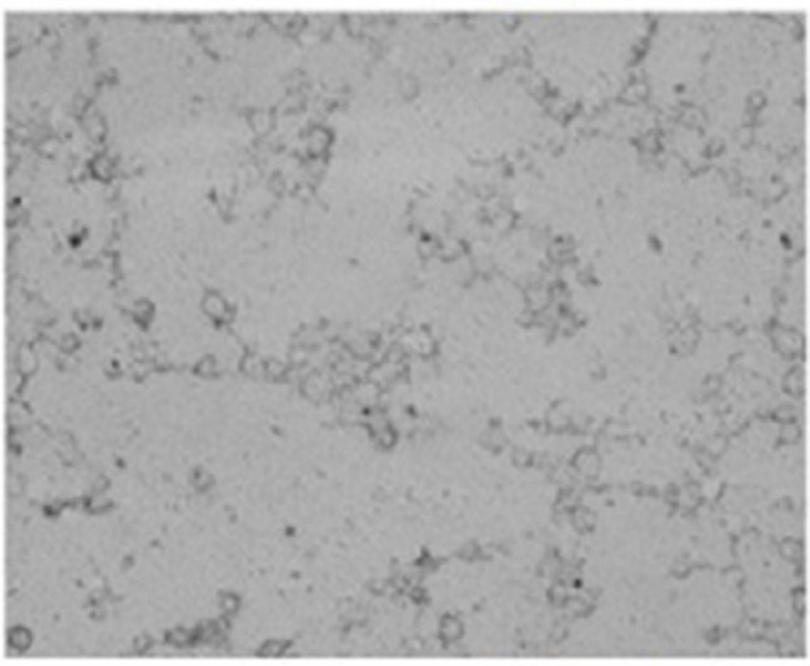

$100 \mu \mathrm{g} / \mathrm{ml}$

Figure 7 Morphological changes induced in MCF-7 cells after exposure at 25, 50, $100 \mu \mathrm{g} / \mathrm{mL}$ FSE-derived ZnO NPs for $24 \mathrm{~h}$ in comparison with the untreated cells (Control).

derived $\mathrm{ZnO} \mathrm{NPs}$, and no antimicrobial activity was displayed with $\mathrm{ZnO}$ alone. The inhibition zone further established the FSE-derived ZnO NPs with significant antimicrobial activity against the selected microorganisms (Table 2).

However, the well diffusion method exhibited the most antimicrobial activity against $E$. faecium VRE $(18.00 \pm 0.04)$ and yeast Cryptococcus sp. (18.00 \pm $0.2 \mathrm{~mm})$, followed by $S$. aureus ATCC 43300 $(17.00 \mathrm{~mm})$ and $P$. aeruginosa and the yeast $C$. parapsilosis ATCC $22019(16 \pm 0.4 \mathrm{~mm})$. These values are the average of two experiments, each of three repetitions. The maximum antimicrobial activities were observed for all the microbial pathogens at the highest concentrations of the FSE-derived ZnO NPs. No activity was observed against $B$. subtilis WS15, K. pneumonia ATCC 13883 and S. typhimurium ATCC 14028 at the lowest concentrations of the FSE-derived $\mathrm{ZnO}$ NPs (Table 2).

Table 2 shows the IZ values obtained treating the ten selected pathogenic bacteria and yeast with the FSEderived $\mathrm{ZnO}$ NPs at the following concentrations: 15, 25 and $50 \mu \mathrm{g} / \mathrm{mL}$ vs conventional antibiotics.

However, bacterial growth inhibition does not mean bacterial death. To distinguish bactericidal and bacteriostatic effects, the MIC was evaluated by the micro- 


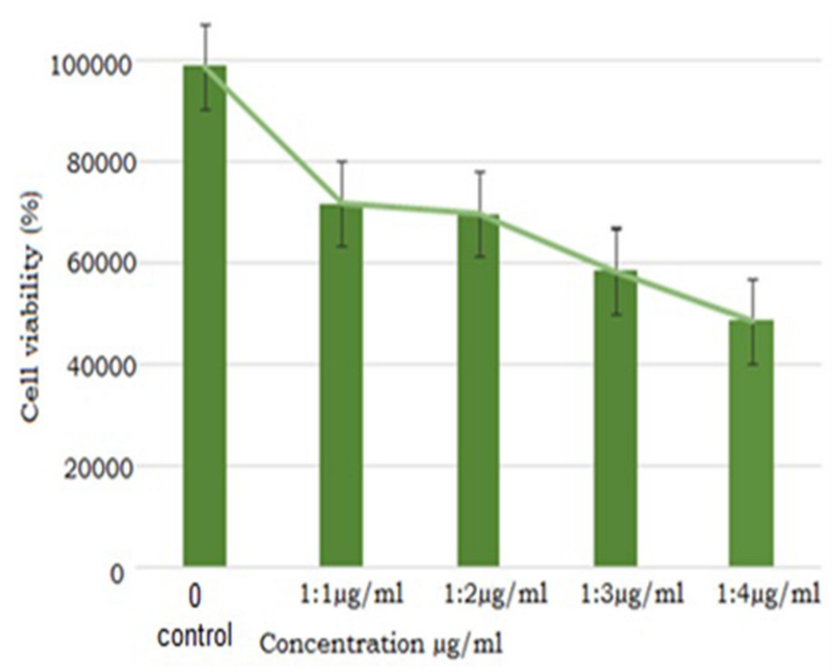

Figure 8 Cell viability of MCF7 cell lines after $24 \mathrm{~h}$ treatment with derived $\mathrm{ZnO}$ NPs with respect to untreated MCF7 cell (Control). dilution test. The MIC values of the ZnO NPs against bacterial strains were $16.00 \mu \mathrm{g} / \mathrm{mL}$ (E. faecium VRE and C. albicans ATCC 8436), $32.00 \mu \mathrm{g} / \mathrm{mL}$ (S. aureus ATCC 43300, $S$. typhimurium ATCC 14028 and Cryptococcus sp.), $64.00 \mu \mathrm{g} / \mathrm{mL}$ (P. aeruginosa), and $128 \mu \mathrm{g} / \mathrm{mL}$ (C. parapsilosis ATCC 22019) (Table 3). Globally, zinc oxide nanoparticles are known for antimicrobial activity and their ability to control microbial pathogens' growth by enabling within the cell membrane. ${ }^{41,42} \mathrm{ZnO}$ NPs antibacterial activity was tested against microbial pathogens (E. coli, E. faecium, S. aureus, S. typhimurium, B. subtilis, K. pneumoniae, and $P$. aeruginosa). This observation showed the suppression of microbial growth, ${ }^{43,44}$ antimicrobial activity to control microbial pathogens' growth by enabling within the cell membrane. ${ }^{32-34}$ The obtained results

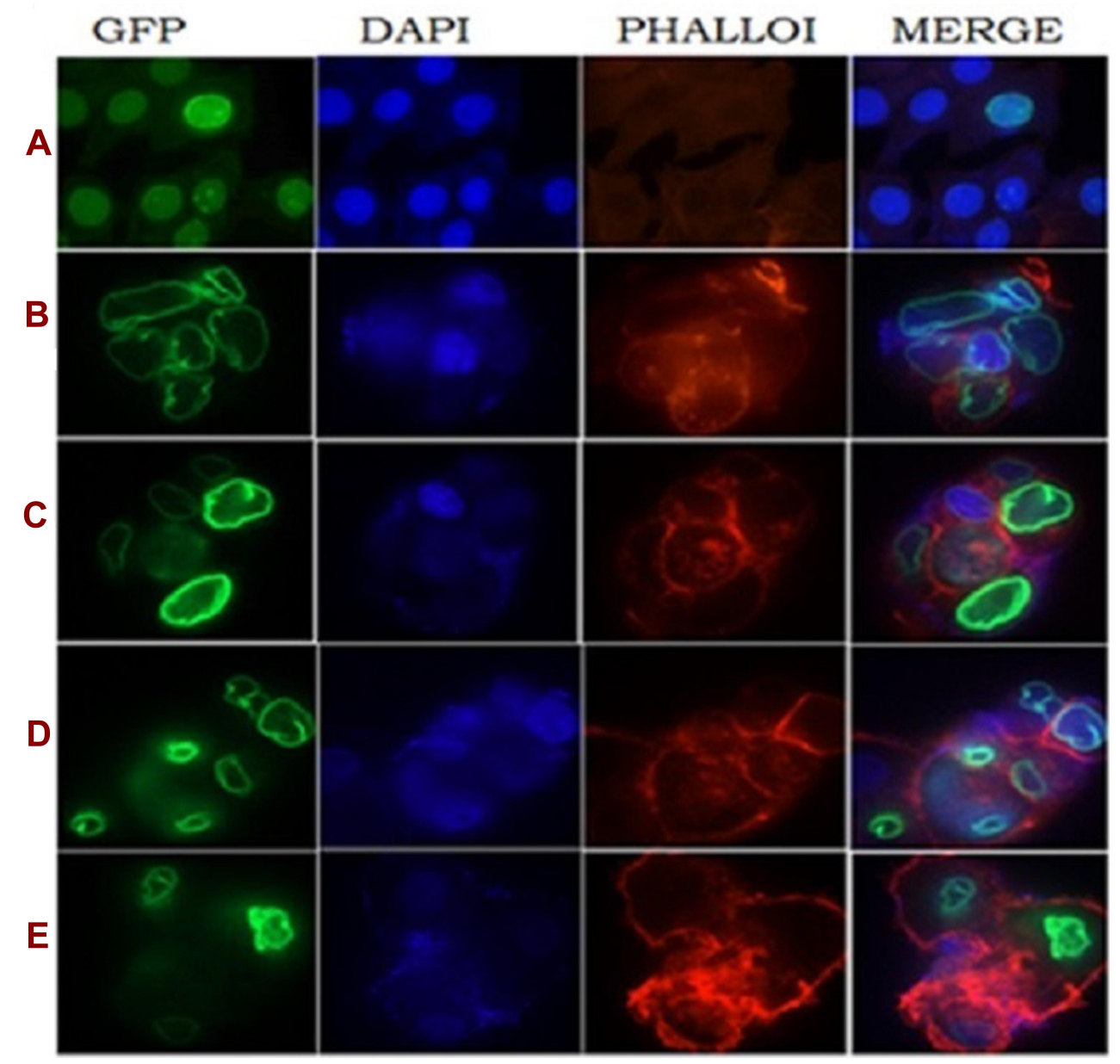

Figure 9 Confocal images of fixed MCF7 cells in culture transected with transiently PCMV6-XL4 GFP expressing vector containing C-terminal domain GFP tagged proteins. (A) Control, showing normal round nuclei for untreated cells and (B-E) showing fragmented nuclei (apoptotic cells) in the treated cells with I:I, I:2, I:3 and I:4 ug/mL of FSE-derived ZnO NPs treatments, respectively. 

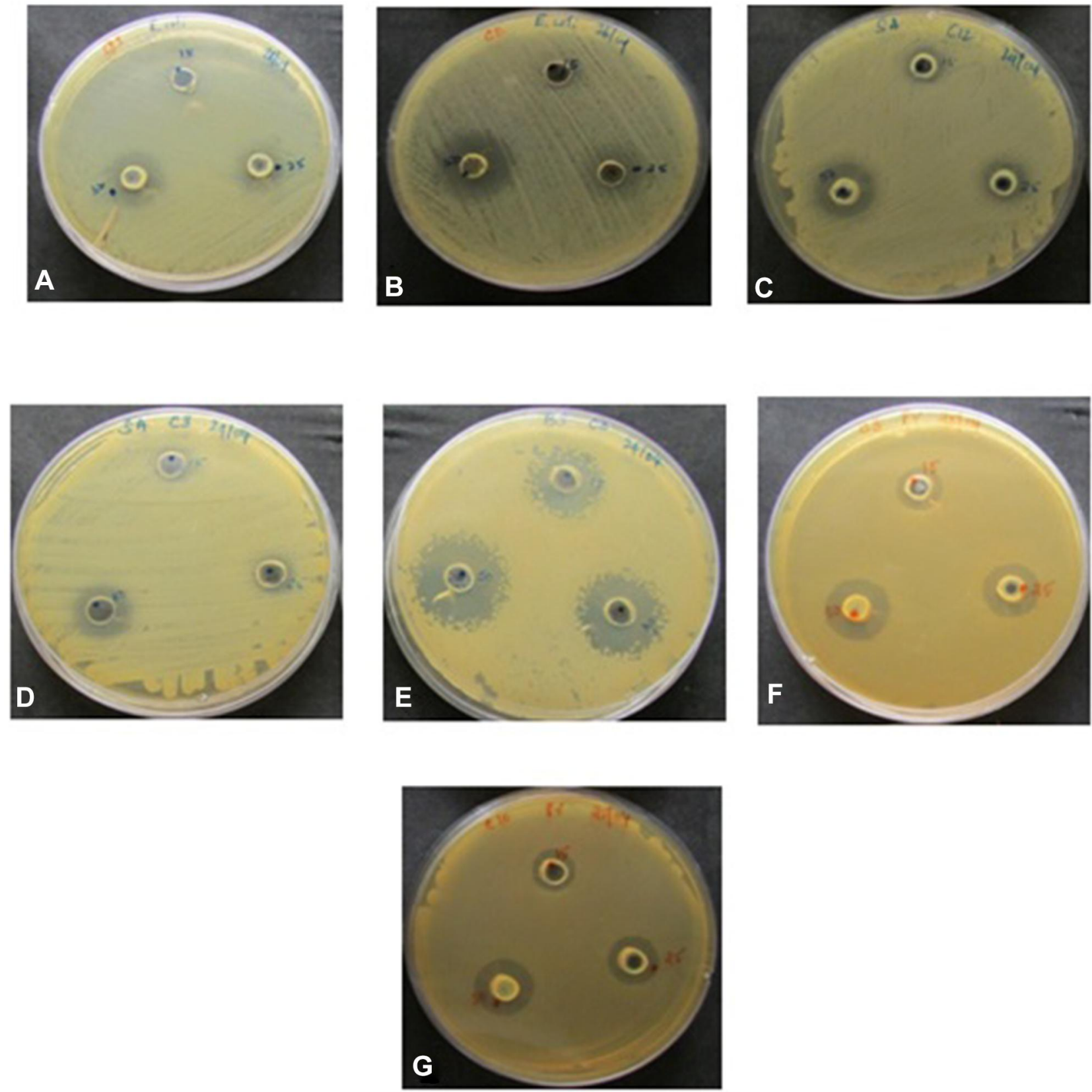

Figure 10 Antibacterial activity of FSE-derived ZnO NPs by well diffusion method: (A) Escherichia coli, (B) Enterococcus faecium, (C) Staphylococcus aureus, (D) Salmonella typhimurium, (E) Bacillus subtilis, (F) Klebsiella pneumoniae, (G) Pseudomonas aeruginosa.

showed significant antimicrobial activity against selected microbial pathogens, ie, E. faecium, S. aureus, P. aeruginosa and $S$. typhimurium, at $50 \mu \mathrm{g}$ of ZnO NPs. The results corroborate earlier reports. ${ }^{7,15,37,41} \mathrm{ZnO}$ NPs attach to the bacterial membrane and damage bacterial cells when extracting the cytoplasmic substances, thus causing the pathogens' death. The FSE suppresses the microbial-growth-derived ZnO NPS more efficiently at the tested pathogens. The novel ZnO NPs, by applying a new natural product technique, project their excellent application as a bioactive compound for diverse biomedical applications.

\section{Conclusion}

This work shows for the first time that the water extract of fennel seed allows the production at room temperature of $\mathrm{ZnO}$ NPs using one-pot synthesis. The green synthesis of the nanoparticles used in this experiment was eco-friendly 
Table 2 Antimicrobial Activity of FSE-Derived ZnO NPs as Compared with Standard Drug Ampicillin and Nystatin

\begin{tabular}{|c|c|c|c|c|}
\hline \multirow[t]{2}{*}{ Microbial Pathogens } & \multicolumn{3}{|c|}{ Zone of Inhibition $(\mathrm{mm}) /$ Concentration $(\mu \mathrm{g} / \mathrm{mL})$} & \multirow[b]{2}{*}{$\mathrm{Amp}^{\#}(10 \mathrm{mcg})$} \\
\hline & 15 & 25 & 50 & \\
\hline \multicolumn{5}{|l|}{ Bacterial pathogens } \\
\hline E. coli ESBL ATCC 9637 & ND* & ND & $12.00 \pm 0.5$ & 14.00 \\
\hline E. faecium VRE & $10.00 \pm 0.2$ & $15.00 \pm 0.1$ & $18.00 \pm 0.4$ & 28.00 \\
\hline S. aureus ATCC 43300 & $11.00 \pm 0.1$ & $14.00 \pm 0.6$ & $17.00 \pm 0.2$ & 9.00 \\
\hline B. subtilis WSI5 & ND & $9.00 \pm 0.2$ & $13.00 \pm 0.3$ & 22.00 \\
\hline P. aeroginosa ATCC 27584 & ND & ND & $16.00 \pm 0.4$ & 12.00 \\
\hline S. typhimurium ATCC 14028 & ND & $12.00 \pm 0.3$ & $15.00 \pm 0.2$ & 20.00 \\
\hline K. pneumoniae ATCC 13883 & ND & $11.00 \pm 0.3$ & $14.00 \pm 0.1$ & 15.00 \\
\hline Fungal pathogens & & & & $\mathrm{Ns}^{\$}(50 \mathrm{mcg})$ \\
\hline C. albicans ATCC 8436 & $8.00 \pm 0.1$ & $12.00 \pm 0.3$ & $15.00 \pm 0.2$ & 13.00 \\
\hline C. parapsilosis ATCC 22019 & ND & $11.00 \pm 0.2$ & $16.00 \pm 0.4$ & 15.00 \\
\hline Cryptococcus sp. & $9.00 \pm 0.2$ & $16.00 \pm 0.3$ & $18.00 \pm 0.2$ & 18.00 \\
\hline
\end{tabular}

Notes: ${ }^{\#}$ Amp, Ampicillin; ${ }^{\$} \mathrm{Ns}$, Nystatin; ${ }^{*} \mathrm{ND}$, Not detect; MIC value of FSE-derived ZnO NPs and standard drug against the selected microbial pathogens grew at $37^{\circ} \mathrm{C}$ (bacteria) and $30^{\circ} \mathrm{C}$ (yeast) for $24 \mathrm{~h}$; the experiment was repeated twice. Tree replication for each experiment.

Table 3 MIC Value of FSE-Derived ZnO NPs Against Microbial Pathogens

\begin{tabular}{|l|l|l|}
\hline \multirow{2}{*}{ Microbial Pathogens } & \multicolumn{2}{|l|}{ MIC Value $(\mu \mathrm{g} / \mathrm{mL})$} \\
\cline { 2 - 3 } & ZnO-NPs & Amp\# (10 mcg) \\
\hline Bacterial pathogens & & \\
E. coli ESBL ATCC 9637 & $>256.00^{*}$ & 64.00 \\
E. faecium VRE & 16.00 & 8.00 \\
S. aureus ATCC 43300 & 32.00 & 16.00 \\
B. subtilis WSI5 & $>256.00^{*}$ & 16.00 \\
P. aeroginosa ATCC 27584 & 64.00 & 16.00 \\
S. typhimurium ATCC 14028 & 32.00 & 16.00 \\
K. pneumoniae ATCC 13883 & $>256.00^{*}$ & 32.00 \\
\hline Fungal pathogens & & $\mathbf{N s}$ (50 mcg) \\
C. albicans ATCC 8436 & 16.00 & 8.00 \\
C. parapsilosis ATCC 22019 & 128.00 & 16.00 \\
Cryptococcus sp. & 32.00 & 16.00 \\
\hline
\end{tabular}

Notes: ${ }^{\# A m p}$, Ampicillin; ${ }^{\$} \mathrm{Ns}$, Nystatin; *Requires high volume of FSE-derived $\mathrm{ZnO} N P s$ required to inhibits the growth of a specific strains.

and nontoxic because of the use of water instead of physical and chemical methods. Water extraction of fennel seed produces more concentrated extracts with higher antioxidant capacity. The presence of phytochemicals in the FSE itself helps in the synthesis of MNPs by inducing redox reactions. The results enhance the therapeutic potential due to the synergy of fennel extract's compounds and $\mathrm{ZnO}$ NPs to exert biological activities as antimicrobial and anticancer activities. Furthermore, higher biocompatibility is expected since it has already been demonstrated for other green synthesized NPS. However, there is a need for in vitro biocompatibility testing before possible applications.

\section{Abbreviations}

FSE, fennel seed extract; XRD, $\mathrm{x}$-ray diffraction analysis; SEM/EDX, scanning electron microscopy/energy-dispersive X-ray; FTIR, Fourier transform infrared spectroscopy; CLSI, Clinical and Laboratory Standards Institute; IC50, the half-maximal inhibitory concentration (IC50) as the effectiveness of a substance in inhibiting a specific biological or biochemical function; MTT, 3-(4,5-dimethylthiazol-2-yl)-2,5-diphenyltetrazolium bromide. GFP, green fluorescent protein; MCF-7, Michigan Cancer Foundation-7, human breast adenocarcinoma cell line; RPM, revolutions per minute; DMEM, Dulbecco's Modified Eagle Medium; DMSO, dimethyl sulfoxide; FBS, fetal bovine serum; EGF, epidermal growth factor; MTT, 3-(4,5-dimethylthiazol-2-yl)-2,5-diphenyltetrazolium bromide; NUR, neutral red uptake; DAPI, 4'-6-diamidino-2-phenylindole; MHA, Muller Hinton agar; MIC, minimum inhibitory concentration; IZ, zone of inhibition $(\mathrm{mm})$; ANOVA, analysis of variance; LSD, last significant difference; PL, photoluminescence; NCMs, nanocrystalline materials; $\mathrm{ZnO} \mathrm{NPs}$, zinc oxide nanoparticles; FCC, face cubic crystal.

\section{Acknowledgments}

The authors are grateful to the Deanship of Scientific Research, King Saud University, for funding through the Vice Deanship of Scientific Research Chairs. 


\section{Funding}

King Saud University through Scientific Research Chairs.

\section{Disclosure}

There are no conflicts of interest for the authors.

\section{References}

1. Bala N, Saha S, Chakraborty M, et al. Green synthesis of zinc oxide nanoparticles using Hibiscus subdariffa leaf extract: effect of temperature on synthesis, anti-bacterial activity and anti-diabetic activity. RSC Adv. 2015;5:4993-5003. doi:10.1039/C4RA12784F

2. Santhoshkumar J, Venkat Kumar S, Rajeshkumar S. Synthesis of zinc oxide nanoparticles using plant leaf extract against urinary tract infection pathogen. Resource-Effic Techno. 2017;3:459-465.

3. AlSalhi MS, Elangovan K, Ranjitsingh AJA, Murali P, Devanesan S. Synthesis of silver nanoparticles using plant derived 4-N-methyl benzoic acid and evaluation of antimicrobial, antioxidant and antitumor activity. Saudi J Biol Sci. 2019;26:970-978. doi:10.1016/j. sjbs.2019.04.001

4. Selim YA, Azb MA, Ragab I, et al. Green synthesis of zinc oxide nanoparticles using aqueous extract of Deverra tortuosa and their cytotoxic activities. Sci Rep. 2020;10:3445. doi:10.1038/s41598-02060541-1

5. AlSalhi MS, Devanesan S, Alfuraydi AA, et al. Green synthesis of silver nanoparticles using Pimpinella anisum seeds: antimicrobial activity and cytotoxicity on human neonatal skin stromal cells and colon cancer cells. Int J Nanomedicine. 2016;11:4439-4449. doi:10.2147/IJN.S113193

6. Alavi M, Karimi N. Biosynthesis of Ag and $\mathrm{Cu}$ NPs by secondary metabolites of usnic acid and thymol with biological macromolecules aggregation and antibacterial activities against multi drug resistant (MDR) bacteria. Int J Biol Macromol. 2019;128:893-901. doi:10. 1016/j.ijbiomac.2019.01.177

7. Jin SE, Jin HE. Synthesis, characterization, and three-dimensional structure generation of zinc oxide-based nanomedicine for biomedical applications. Pharmaceutics. 2019;11:575. doi:10.3390/pharmaceutics11110575

8. Smijs TG, Pavel S. Titanium dioxide and zinc oxide nanoparticles in sunscreens: focus on their safety and effectiveness. Nanotechnol Sci Appl. 2011;4:95-112. doi:10.2147/NSA.S19419

9. Xiao FX, Hung SF, Tao HB, Miao J, Yang HB, Liu B. Spatially branched hierarchical $\mathrm{ZnO}$ nanorod- $\mathrm{TiO}_{2}$ nanotube array heterostructures for versatile photocatalytic and photo-electrocatalytic applications: towards intimate integration of 1D-1D hybrid nanostructures. Nanoscale. 2014;6:14950-14961.

10. Mikhailov OV, Mikhailova EO. Elemental silver nanoparticles: biosynthesis and bio applications. Materials. 2019;12:3177.

11. Nunes JP, Fernandes B, Fertunato E, Vilarinho P, Martins R. Performances presented by zinc oxide thin films deposited by spray pyrolysis. Thin Solid Films. 1999;337:176-179. doi:10.1016/S00406090(98)01394-7

12. Jiang J, Pi J, Cai J. The advancing of zinc oxide nanoparticles for biomedical applications. Bioinorg Chem Appl. 2018;2018:1-18. doi:10.1155/2018/1062562

13. Newman MD, Stotland M, Ellis JI. The safety of nanosized particles in titanium dioxide- and zinc oxide-based sunscreens. $J$ Am Acad Dermatol. 2009;61:685-692. doi:10.1016/j.jaad.2009.02.051

14. Haritha M, Meena V, Seema CC, Srinivasa RB. Synthesis and characterization of zinc oxide nanoparticles and its antimicrobial activity against Bacillus subtilis and Escherichia coli. Rasayan $J$ Chem. 2011;4:217-222.

15. Xie Y, He Y, Irwin PL, Jin T, Shi X. Antibacterial activity and mechanism of action of zinc oxide nanoparticles against Campylobacter jejuni. Appl Environ Microbiol. 2011;77:2325-2331. doi:10.1128/AEM.02149-10
16. Venkatasubbu GD, Baskar R, Anusuya T, Seshan CA, Chelliah R. Toxicity mechanism of titanium dioxide and zinc oxide nanoparticles against food pathogens. Colloids Surface B. 2016;148:600-606. doi:10.1016/j.colsurfb.2016.09.042

17. Lee JH, Kim YG, M H C, Lee J. ZnO nanoparticles inhibit Pseudomonas aeruginosa biofilm formation and virulence factor production. Microbiol Res. 2014;169:888-896. doi:10.1016/j.micres.20 14.05.005

18. Alavi M, Nokhodchi A. An overview on antimicrobial and wound healing properties of $\mathrm{ZnO}$ nanobiofilms, hydrogels, and bionanocomposites based on cellulose, chitosan, and alginate polymers. Carbohydr Polym. 2020;227:115349. doi:10.1016/j.carbpol.2019.11 5349

19. Omri K, Najeh I, Dhahri R, El Ghoul J, Elmir L. Effects of temperature on the optical and electrical properties of $\mathrm{ZnO}$ nanoparticles synthesized by sol-gel method. Microelectron Eng. 2014;128:5358. doi:10.1016/j.mee.2014.05.029

20. Wang Y, Zhang C, Bi S, Luo G. Preparation of $\mathrm{ZnO}$ nanoparticles using the direct precipitation method in a membrane dispersion micro-structured reactor. Powder Technol. 2010;202:130-136. doi:10. 1016/j.powtec.2010.04.027

21. Moisa C, Copolovici L, Bungau S, et al. Wastes resulting from aromatic plants distillation-bio-sources of antioxidants and phenolic compounds with biological active principles. Farmacia. 2018; 66:289-295.

22. Boyadzhieva S, Angelov G. Optimization of water extraction of fennel seeds. Chem Technol Metall. 2014;49:447-450.

23. Boyadzhieva S, Angelov G, Georgieva S, Yankov D. Characterization of polyphenol content and antioxidant capacity of spent coffee grounds. Bulg Chem Commun. 2018;50:85-89.

24. Doan TTU, Nguyen TT, Thi YD, Ta Thi KH, Phan BT, Pham KN. Green synthesis of $\mathrm{ZnO}$ nanoparticles using orange fruit peel extract for antibacterial activities. RSC $A d v$. 2020;10:23899-23907. doi:10. 1039/D0RA04926C

25. Atif M, Fakhar-e-Alam M, Zaidi SSZ, Suleman R. Study of the efficacy of photofrin ${ }^{\circledR}$-mediated PDT on human hepatocellular carcinoma (HepG2) cell line. Laser Phys. 2011;21:1135-1144. doi:10.1134/S1054660X11110028

26. Atif M, Malik AR, Fakhar-e-Alam M, et al. In vitro studies of Photofrin ${ }^{\circledR}$ mediated photodynamic therapy on human rhabdomyosarcoma cell line (RD). Laser Phys. 2012;22:286-293. doi:10.1134/ S1054660X11230010

27. Devanesan S, Ponmurugan K, AlSalhi MS, Al-Dhabi NA. Cytotoxic and antimicrobial efficacy of silver nanoparticles synthesized using a traditional phytoproduct, asafoetida gum. Int $J$ Nanomedicine. 2020;15:4351-4362. doi:10.2147/IJN.S258319

28. Clinical and Laboratory Standards Institute (CLSI), 2012. Performance Standards for Antimicrobial Susceptibility Testing. 27th. CLSI supplement M100 (ISBN 1-56238-804-5 [Print]; ISBN 1-56238-805-3 [Electronic]). Pennsylvania 19087 USA: Clinical and Laboratory Standards Institute; 2017.

29. Punjabi K, Mehta S, Chavan R, Chitalia V, Deogharkar D, Deshpande S. Efficiency of biosynthesized silver and zinc nanoparticles against multi-drug resistant pathogens. Front Microbiol. 2018;9:2207. doi:10.3389/fmicb.2018.02207

30. Miller RA, Walker RD, Carson J, et al. Standardization of a broth microdilution susceptibility testing method to determine inhibitory concentrations of aquatic bacteria. Dis Aquat Organ. 2005;64:211222. doi:10.3354/dao064211

31. Angelov G, Boyadzhieva S. Extraction of fennel (Foeniculum vulgare) seeds: process optimization and antioxidant capacity of the extracts. Chem Biochem Eng. 2016;30:245-253. doi:10.15255/ CABEQ.2015.2281

32. Raut $\mathrm{S}$, Thorat PV, Thakre R. Green synthesis of zinc oxide $(\mathrm{ZnO})$ nanoparticles using Ocimum tenuiflorum leaves. Int J Sc I Res. 2013;14:2319-7064. 
33. Mishra V, Sharma R. Green synthesis of zinc oxide nanoparticles using fresh peels extract of Punica granatum and its antimicrobial activities. Spectrochimi Acta-Part A. 2015;143:158-164. doi:10.10 16/j.saa.2015.02.011

34. Mirzaei H, Darroudi M. Zinc oxide nanoparticles: biological synthesis and biomedical applications. Ceram Int. 2017;43:907-914. doi:10.1016/j.ceramint.2016.10.051

35. Atif M, Iqbal S, Fakhar-e-Alam M, et al. Manganese doped cerium oxide nanocomposite induced photodynamic therapy in MCF-7 cancer cells and antibacterial activity. Biomed Res Int. 2019;20 19:7156828. doi:10.1155/2019/7156828

36. Atif M, Fakhar-e-Alam M, Abbas N, et al. In vitro cytotoxicity of mesoporous $\mathrm{SiO}_{2} @ \mathrm{Eu}(\mathrm{OH})^{3}$ core-shell nanospheres in MCF-7. J Nanomater. 2016;2016:7691861.

37. Rodríguez-León E, Rodríguez-Vázquez BE, Martínez-Higuera A, et al. Synthesis of gold nanoparticles using Mimosa tenuiflora extract, assessments of cytotoxicity, cellular uptake, and catalysis. Nanoscale Res Lett. 2019;14:334. doi:10.1186/s11671-0193158-9

38. Wang J, Lee JS, Kim D, Zhu L. Exploration of zinc oxide nanoparticles as a multitarget and multifunctional anticancer nanomedicine. ACS Appl Mater Interfaces. 2017;9:39971-39984. doi:10.1021/ acsami.7b11219
39. Wang J, Gao S, Wang S, Xu Z, Wei L. Zinc oxide nanoparticles induce toxicity in CAL 27 oral cancer cell lines by activating PINK1/ Parkin-mediated mitophagy. Int J Nanomed. 2018;13:3441. doi:10. 2147/IJN.S165699

40. Megeressa M, Do V, Ahmed A. Cytotoxic activity of proteins extracted from fennel (Foeniculum vulgare) seeds against human cancer cell lines. FASEB J. 2020;34:1. doi:10.1096/fasebj.2020.34.s1.06422

41. Divyapriya S, Sowmia C, Sasikala S. Synthesis of zinc oxide nanoparticles and antimicrobial activity of Murraya Koenigii. Int J Pharm Pharm Sci. 2014;3:1635-1645.

42. Ramani M, Ponnusamy S, Muthamizhchelvan C, Marsili E. Amino acid-mediated synthesis of zinc oxide nanostructures and evaluation of their facet-dependent antimicrobial activity. Colloids Surf B Biointerfaces. 2014;117:233-239. doi:10.1016/j.colsurfb.2014.02.017

43. Jan T, Iqbal J, Ismail M, Zakaullah M, Haider Naqvi S, Badshah N. $\mathrm{Sn}$ doping induced enhancement in the activity of $\mathrm{ZnO}$ nanostructures against antibiotic resistant S. aureus bacteria. Int J Nanomed. 2013;8:3679-3687. doi:10.2147/IJN.S45439

44. Devanesan S, AlSalhi MS, Balaji RV, et al. Antimicrobial and cytotoxicity effects of synthesized silver nanoparticles from Punica granatum peel extract. Nanoscale Res Lett. 2018;13:315. doi:10.1186/ s11671-018-2731-y
International Journal of Nanomedicine

\section{Publish your work in this journal}

The International Journal of Nanomedicine is an international, peerreviewed journal focusing on the application of nanotechnology in diagnostics, therapeutics, and drug delivery systems throughout the biomedical field. This journal is indexed on PubMed Central, MedLine, CAS, SciSearch ${ }^{\mathbb{R}}$, Current Contents ${ }^{\mathbb{B}} /$ Clinical Medicine, $^{2}$
Dovepress

Journal Citation Reports/Science Edition, EMBase, Scopus and the Elsevier Bibliographic databases. The manuscript management system is completely online and includes a very quick and fair peer-review system, which is all easy to use. Visit http://www.dovepress.com/ testimonials.php to read real quotes from published authors. 